\title{
E-retailers' competitive intensity: A positioning mapping analysis
}

Received (in revised form): 8th August, 2003

\begin{abstract}
Noam Tractinsky
is a senior lecturer in the Department of Information Systems Engineering Sciences, Faculty of Engineering at Ben-Gurion University of the Negev. His research interests are in the area of human-computer interfaces, management information systems, decision support systems and the social dimension of web retailing. His papers have appeared in high-quality academic journals. He has a PhD from the University of Texas at Austin in the USA.
\end{abstract}

\section{Oded Lowengart}

is a senior lecturer at the Department of Business Administration at the School of Management at Ben-Gurion University of the Negev, Israel. His research interests are in the areas of pricing effects on consumer choice, international marketing, product positioning and market share forecasting and diagnostic. His papers have appeared in high-quality academic journals. He has a PhD from the University of Wisconsin-Milwaukee in the USA.

\begin{abstract}
The downturn of the internet economy has made it clear that e-retailers need to become more competitive if they are to survive. One way for retailers to gauge their competitiveness is by considering their position on various key perceptual dimensions of the retail environment. This study suggests the use of two analytical tools - perceptual maps and gap analysis - to help managers improve their ability to gauge and improve their competitive position. In this study, data from a previous study are used to demonstrate the use of the two tools in two different competitive environments. The paper describes how the tools can be used to reveal similarities and differences between e-retailers, to identify the ideal combinations of important perceptual factors in the context of the retail domain of these stores, to locate the e-retailer's position relative to the ideal combination and to suggest directions for improving website design.
\end{abstract}

\section{INTRODUCTION}

The introduction of e-commerce has dramatically changed the rules of the game of marketing. ${ }^{1}$ Thanks to the power of telecommunications and information technologies, consumers can now access information about more vendors more easily than ever before. Moreover, new software tools make it easy for consumers to compare and assess quality, image and price. The end result of this might be shrinking the already diminishing profits of today's vendors even further. ${ }^{2}$ The recession in general and that of the dot.com economy in particular intensify the sense of urgency among e-retailers who face stiff competition in their struggle to survive today's harsh economic realities. The slow economy, coupled with the crowded field of competitors in business-to-consumer (B2C) e-commerce make it apparent that achieving long-term success in web retailing requires a store to adhere to traditional economic and marketing principles and apply traditional marketing strategies. In Patton's words 'the companies and individuals that have succeeded on the Web aren't necessarily those that jumped in first or developed the most novel strategies. Instead, many have focused on simplicity and on applying traditional business thinking to a new channel'. ${ }^{3}$

These trends increase the importance 
of how potential consumers view retail stores. Previous studies have indicated that consumer perception of websites are affected by various design decisions made by the retailer and at the same time are an important determinant of user intentions to shop at those sites. ${ }^{4-6}$ Despite increasing academic interest in consumer internet shopping behaviour, however, much of this research concentrates on evaluations of web-based retailers rather than on selection of one retailer over another. This study demonstrates how the application of two analytical tools - perceptual maps and gap analysis - can serve web-based retailers by allowing them to understand how they are perceived by consumers on key store characteristics, and how these perceptions position them vis-à-vis the competition. In the following sections the groundwork for this study is laid by surveying the general characteristics of research on consumer behaviour in the e-retail environment and the idea of competitive positioning.

\section{STUDIES OF CONSUMER BEHAVIOUR IN THE E-RETAIL ENVIRONMENT}

There is a growing body of research on consumer behaviour in electronic retail settings. Little research has been done to date, however, on the specific problem of why consumers prefer one web-based retailer to another. Most of the academic research on e-retail has focused on three themes. One line of research has studied the general tendencies of consumers to shop on the web. ${ }^{7-10}$ This line of research is most commonly concerned with questions regarding consumer readiness to buy from online stores in general. Another branch of B2C research has focused on how users evaluate specific brands that are offered through the web. ${ }^{11}$ The third type of research deals with how consumers evaluate specific online retailers and how they compare virtual stores. ${ }^{12-15}$ Of the three lines of research delineated above, only the latter deals with issues close to the question of how web-retailers are positioned relative to their competitors. Within this line it is possible to identify studies that concentrate on rating various stores, ${ }^{16}$ studies that focus on deciding whether to buy from a specific, single, store, ${ }^{17}$ and studies that concentrate on consumer decisions regarding which store to buy from, given a set of alternative stores. ${ }^{18}$ Again, it is this latter type of research, ie research that studies how consumers choose between different stores, that is pertinent to the study of web store positioning vis-à-vis the competition.

In addition to this thematic classification of consumer behaviour in e-commerce research, it is also important to note that findings might be contingent upon the type of products sought. Thus, Jarvenpaa et al. ${ }^{19}$ found that consumers weigh various store attributes differently when shopping for low or high-risk products. Zhang and her colleagues found that user evaluations of internet sites depend on the site domain. ${ }^{20,21}$ That is, different attributes were weighted differently depending on the type of product or service offered by those sites. Similarly, Lowengart and Tractinsky ${ }^{22}$ have compared the consumer choice process of buying online computers and books. They found that consumers weighted various perceptual characteristics of the e-retailer differently depending on the product for which they were shopping.

Perhaps due to the booming e-economy and the perception that the end of its exponential growth rate is not yet in sight, retailers as well as researchers were not as concerned about intra-industry competition as they used 
to be in the age of the 'old economy.' The downturn of the internet economy has necessitated a shift in this approach. It is clear now that e-retailers need to become more competitive if they are to survive. One way in which retailers can gauge their competitiveness is by considering their position on various key perceptual dimensions of the retail environment. ${ }^{23}$

\section{COMPETITIVE POSITIONING}

Product positioning is a well-established concept in marketing literature. ${ }^{24}$ Loosely defined, positioning is the way a firm designs and presents its image to potential customers such that the target audiences understand what the firm offers relative to other firms in the same marketplace. Positioning is in the mind of the customer, something that is brought about by a combination of reality and image: 'Competitive positioning is the totality of offer and image of the company relative to competing companies'. ${ }^{25}$ For positioning to be effective, a retailer has to offer tangible, important and communicable benefits to target customers. ${ }^{26}$ The concept of positioning is broad enough to be extended beyond the product and the firm, eg to the realm of the country and its resources ${ }^{27}$ or even to encompass an entire continent. ${ }^{28}$

Constructing a map that reflects the positioning of a commercial entity allows managers to achieve two main objectives in defining their marketing strategies. The first objective is gaining more insight into the competitive positioning of their firm compared to that of other rival firms. In addition, by studying this map, managers may be able to find 'open' spaces in the competitive environment, allowing them, for example, to reposition themselves as more attractive than the competition.
Thus, providing mapping tools for retailer positioning can enhance the ability of managers to improve their business and attract and retain customers.

Wind and Mahajan suggest that many failed dot.com companies had a flawed understanding of their customers. ${ }^{29}$ They also failed to apply traditional marketing tools to assess the challenges they were facing. For example, e-retailers try to profile users. ${ }^{30,31}$ Yet, e-retailers also need to be aware of how their profile is perceived by consumers. This truism of the old economy has not been attended to by past studies of web-based retail. It is the purpose of this study to propose a method for studying this aspect of e-retail. Thus, the current study concentrates on how consumers perceive alternative e-retailers. The paper proposes and demonstrates two analytical tools that can assist in conveying user perceptual profiling of e-retailers in two different domains. It is demonstrated that such profiling is feasible and is also sensitive to the domain within which the e-retailer is situated. More specifically, the techniques of gap analysis and positioning maps are used to reveal similarities and differences between e-retailers. Then the ideal combinations of important perceptual factors are shown in the context of the retail domain of these stores.

The analytical tools are presented in the next section. Following that, how this methodology can be effectively implemented in different domains of e-commerce is demonstrated using data regarding three bookstores and three computer stores.

\section{METHOD}

\section{Database}

To illustrate the viability of the competitive positioning analysis tools proposed in this study, data from a study 
Table 1: Items used in the study questionnaire

1 The site belongs to a large store

2 The site belongs to a reputable store

3 Finding information on the site is easy

4 The website makes shopping easy

5 The site's design is beautiful

6 This site uses good mechanisms of data security

7 This site provides good service

8 The site's operators will not put my privacy in jeopardy

9 The site provides complete information about the costs associated with a purchase

$10 \mathrm{I} \mathrm{am}$ interested in the products that are sold on this site

11 The site has a wide range of products

12 The site provides attractively priced merchandise

13 Shopping on this site is fun

14 The site's operators are reliable

15 Shopping on this site might lead to monetary losses for me

16 The site provides detailed description of the products

17 The information on this site is reliable

18 This site is a source of high-quality products

19 Products on this site are displayed in a visually appealing manner

20 Products on this site do not meet my expectations

21 The site provides up-to-date information to potential customers

by Lowengart and Tractinsky ${ }^{32}$ are used. The data in that study were obtained from 114 participants using a semi-experimental procedure.

Seventy-two of the participants were male (63 per cent) and 42 female (37 per cent), with an average age of 23 .

Participants in that study evaluated three e-retailers in the computer hardware domain and three e-retailers in the bookstore domain across 21 different store characteristics (see Table 1).

Using factor analysis, ${ }^{33}$ four factors that affect consumer evaluations of online bookstores and six factors that affect evaluations of online computer stores were identified. The four factors that emerged from the data on bookstores represent the shopping process, the quality of the product, risks involved in shopping from the store and the size and reputation of the store (see Table 2). The six factors affecting intent to buy from the computer stores only partially overlapped with those of the bookstore. These factors were the shopping process, the quality of the information about the product, monetary risks involved in the purchase, other risks involved in the purchase, the quality of the product itself and the size and reputation of the store (see Table 3). The main differences between the two types of merchandise indicate that when consumers shopped for computers, they placed greater emphasis on the risks associated with purchasing the product than when shopping for books. Such differences are commensurate with the differences between experience-quality, expensive products (eg computers) and searchquality, inexpensive products (eg books). Indeed, the literature on e-retailing portrays a central role for risk in consumer behaviour. Risk in this context can stem from two main sources: perceptions of the uncertainty associated with the buying process and the magnitude of a loss (eg monetary, of effort or time, or emotional) that might transpire eventually. ${ }^{34}$ Further, the literature on risk in internet shopping also distinguishes between channel risk (ie the general risk of buying through the internet), store risk (ie the specific risk associated with a particular vendor) and product risk. ${ }^{35}$ These issues closely overlap with general issues of consumer 
Table 2: Rotated component matrix - bookstores

\begin{tabular}{|c|c|c|c|c|}
\hline & \multicolumn{4}{|c|}{ Factors and per cent of explained variance } \\
\hline & $\begin{array}{l}1 \\
41.69 \%\end{array}$ & $\begin{array}{l}2 \\
8.50 \%\end{array}$ & $\begin{array}{l}3 \\
7.56 \%\end{array}$ & $\begin{array}{l}4 \\
4.87 \%\end{array}$ \\
\hline The site belongs to a large store & 0.09 & 0.18 & 0.02 & 0.91 \\
\hline The site belongs to a reputable store & 0.07 & 0.11 & 0.15 & 0.91 \\
\hline Finding information on the site is easy & 0.75 & 0.29 & 0.08 & 0.05 \\
\hline The website makes shopping easy & 0.69 & 0.13 & 0.28 & 0.00 \\
\hline The site's design is beautiful & 0.72 & 0.09 & 0.01 & 0.26 \\
\hline This site uses good mechanisms of data security & 0.34 & 0.00 & 0.68 & 0.22 \\
\hline This site provides good service & 0.67 & 0.35 & 0.35 & 0.10 \\
\hline The site's operators will not put my privacy in jeopardy & 0.19 & 0.15 & 0.76 & 0.15 \\
\hline $\begin{array}{l}\text { The site provides complete information about the costs } \\
\text { associated with a purchase }\end{array}$ & 0.52 & 0.26 & 0.38 & 0.02 \\
\hline I am interested in the products that are sold on this site & 0.35 & 0.55 & -0.10 & 0.14 \\
\hline The site has a wide range of products & 0.57 & 0.59 & 0.07 & 0.06 \\
\hline The site provides attractively priced merchandise & 0.40 & 0.56 & 0.06 & 0.13 \\
\hline Shopping on this site is fun & 0.79 & 0.35 & 0.12 & 0.06 \\
\hline The site's operators are reliable & 0.25 & 0.37 & 0.62 & 0.05 \\
\hline $\begin{array}{l}\text { Shopping on this site might lead to monetary losses for } \\
\text { me }[R]\end{array}$ & -0.06 & 0.09 & 0.64 & -0.10 \\
\hline The site provides detailed description of the products & 0.72 & 0.40 & 0.18 & -0.06 \\
\hline Information on this site is reliable & 0.24 & 0.62 & 0.42 & 0.08 \\
\hline This site is a source of high-quality products & 0.18 & 0.68 & 0.24 & 0.16 \\
\hline $\begin{array}{l}\text { Products on this site are displayed in a visually appealing } \\
\text { way }\end{array}$ & 0.77 & 0.23 & 0.10 & 0.07 \\
\hline Products on this site do not meet my expectations $[R]$ & 0.18 & 0.60 & 0.22 & 0.04 \\
\hline $\begin{array}{l}\text { The site provides up-to-date information to potential } \\
\text { customers }\end{array}$ & 0.60 & 0.54 & 0.20 & -0.01 \\
\hline Cronbach Alpha & 0.90 & 0.71 & 0.57 & $0.76^{*}$ \\
\hline
\end{tabular}

* Pearson correlation coefficient

Note: The bolded entries under each factor (column) indicate which attributes (rows) belong to this factor

behaviour on the internet, ${ }^{36}$ as discussed above. Whereas this paper does not deal with the issue of internet shopping risk relative to other channels, the study was designed to address the other two risk issues mentioned above.

\section{Analysis tools}

In this study two analysis tools are employed to demonstrate how e-retailers can assess their positioning relative to the competition. The outcomes of the analyses can be presented in a visual form, and the values that each e-store scores on any of the analyses can be juxtaposed against the scores of its competitors to facilitate understanding of its position. The two tools are discussed in the following subsections.

Subsequently, the effectiveness of said tools is demonstrated by using the data gathered by Lowengart and Tractinsky. ${ }^{37}$

\section{Gap analysis}

Perceptual gap analysis determines the proximity of internet shopping sites to each other. The tool investigates the spatial difference among the stores in the competitive space, by examining consumer perceptions of the competing e-retailers in terms of key store characteristics. Thus, this tool facilitates the discovery of similarities and differences among the competing internet shopping sites.

\section{Positioning maps}

The second analytical tool enables comparison of the differences in relative perceptions of the different characteristics of each store. ${ }^{38,39}$ This analysis allows 
Table 3: Rotated component matrix - Computer stores

\begin{tabular}{|c|c|c|c|c|c|c|}
\hline & \multicolumn{5}{|c|}{ Factors and per cent of explained variance } & \multirow[b]{2}{*}{$\begin{array}{l}6 \\
4.71 \%\end{array}$} \\
\hline & $\begin{array}{l}1 \\
36.82 \%\end{array}$ & $\begin{array}{l}2 \\
7.92 \%\end{array}$ & $\begin{array}{l}3 \\
6.14 \%\end{array}$ & $\begin{array}{l}4 \\
5.56 \%\end{array}$ & $\begin{array}{l}5 \\
5.04 \%\end{array}$ & \\
\hline The site belongs to a large store & 0.15 & 0.14 & 0.25 & 0.85 & 0.06 & 0.02 \\
\hline The site belongs to a reputable store & 0.16 & 0.17 & 0.27 & 0.81 & 0.07 & 0.06 \\
\hline Finding information on the site is easy & 0.58 & 0.42 & 0.07 & 0.29 & 0.20 & -0.05 \\
\hline The website makes shopping easy & 0.72 & 0.13 & 0.16 & -0.01 & 0.10 & 0.00 \\
\hline The site's design is beautiful & 0.82 & 0.14 & 0.11 & 0.06 & 0.11 & 0.00 \\
\hline $\begin{array}{l}\text { This site uses good mechanisms of data } \\
\text { security }\end{array}$ & 0.16 & 0.09 & 0.69 & 0.22 & 0.06 & -0.04 \\
\hline This site provides good service & 0.57 & 0.36 & 0.40 & 0.11 & 0.08 & 0.16 \\
\hline $\begin{array}{l}\text { The site's operators will not put my privacy } \\
\text { in jeopardy }\end{array}$ & 0.19 & 0.00 & 0.75 & 0.18 & 0.04 & -0.03 \\
\hline $\begin{array}{l}\text { The site provides complete information about } \\
\text { the costs associated with a purchase }\end{array}$ & 0.38 & 0.61 & 0.10 & 0.11 & 0.00 & 0.02 \\
\hline $\begin{array}{l}\text { I am interested in the products that are sold } \\
\text { on this site }\end{array}$ & 0.09 & 0.20 & 0.14 & -0.03 & 0.76 & -0.13 \\
\hline The site has a wide range of products & 0.30 & 0.58 & 0.05 & 0.30 & 0.33 & -0.04 \\
\hline $\begin{array}{l}\text { The site provides attractively priced } \\
\text { merchandise }\end{array}$ & 0.13 & 0.68 & 0.18 & -0.08 & 0.15 & -0.04 \\
\hline Shopping on this site is fun & 0.74 & 0.29 & 0.20 & 0.14 & 0.10 & 0.02 \\
\hline The site's operators are reliable & 0.14 & 0.41 & 0.67 & 0.09 & 0.12 & 0.16 \\
\hline $\begin{array}{l}\text { Shopping on this site might lead to monetary } \\
\text { losses for me }[R]\end{array}$ & -0.04 & 0.07 & 0.07 & 0.02 & -0.07 & 0.91 \\
\hline $\begin{array}{l}\text { The site provides detailed description of the } \\
\text { products }\end{array}$ & 0.38 & 0.55 & 0.01 & 0.38 & 0.06 & -0.05 \\
\hline Information on this site is reliable & 0.14 & 0.61 & 0.35 & 0.15 & 0.23 & 0.21 \\
\hline This site is a source of high-quality products & 0.13 & 0.31 & 0.38 & 0.20 & 0.57 & 0.02 \\
\hline $\begin{array}{l}\text { Products on this site are displayed in a } \\
\text { visually appealing manner }\end{array}$ & 0.72 & 0.28 & 0.08 & 0.24 & -0.01 & -0.04 \\
\hline $\begin{array}{l}\text { Products on this site do not meet my } \\
\text { expectations }[R]\end{array}$ & 0.20 & -0.11 & -0.31 & 0.13 & 0.56 & 0.45 \\
\hline $\begin{array}{l}\text { The site provides up-to-date information to } \\
\text { potential customers }\end{array}$ & 0.41 & 0.65 & 0.00 & 0.24 & -0.01 & 0.06 \\
\hline Cronbach Alpha & 0.88 & 0.83 & 0.71 & $0.76^{\star}$ & 0.46 & NA \\
\hline
\end{tabular}

* Pearson correlation coefficient

Note: The bolded entries under each factor (column) indicate which attributes (rows) belong to this factor

determination of which characteristics do not have similar impact on customer perception in evaluating specific internet shopping sites. It also enables the relative importance of a specific characteristic in the competitive domain to be determined.

The construction of a positioning map that reflects this type of concept allows managers to achieve two main objectives when implementing their marketing strategies. Namely, gaining more insight into the competitive positioning of their business compared to that of rival e-retailers by comparing the distance of their e-store to the others. In addition, by studying this map, managers may be able to find 'holes' that might indicate 'open' spaces in the competitive environment, giving them, for example, the ability to reposition themselves as more attractive than the competition. This competitive positioning can vary across different store types. For example, consumers may look for different store characteristics when buying online high-risk products (eg computers) than when buying low-risk products (eg books). Thus, marketers can use various tools, such as changing the perception of certain characteristics via the design of their site, to reposition their firm. Thus, it is clear that examining the use of positioning mapping as a tool for managers in designing their strategies to attract consumers is indeed important. 


\section{Approach}

The methodology included the following steps: in the first stage positioning maps were constructed. After constructing the maps, the consumer preference data were used to determine the ideal vector of the stores' positions in the particular competitive settings (ie bookstores or computer hardware stores). That is, the ideal combination of web store dimensions that consumers seek when making purchase decisions was identified. Once this vector is superimposed on the positioning map, the proximity of each e-retailer to that vector determines its attractiveness to consumers. In the second stage perceptual gaps were used to identify the specific site characteristics that contributed to perceptual discrimination between alternative e-retailers. Below, a more in-depth explanation of these analyses and how they were employed in the current study is provided.

Positioning maps were constructed in the first stage to evaluate the differences (or similarities) among the three internet shopping sites. Because positioning maps involve the graphic representation of data, their legibility and effectiveness are limited to the use of only a few dimensions. Thus, the general perceptual factors of the e-retailers that emerged from Lowengart's and Tractinsky's study ${ }^{40}$ were used rather than the 21 raw characteristics that formed the basis of the general factors. The positioning maps were constructed on the basis of the factors' scores of different extracted factors. The outcome of this analysis enables the determination of consumer perceptual discrimination among the three e-retailers in a specific domain (in this case, either computer hardware or bookstores).

Positioning maps, however, cannot completely solve the puzzle of understanding consumer perceptions and preferences with respect to online shopping. There are still two missing pieces: (1) the distance between the perceived site characteristics and the preferred characteristics (the closer the gap between perceptions and preferences, the more likely consumers are to purchase from the site); and (2) the relative contribution of the specific characteristic to the differences in the positioning of the e-retailers. Note that the factor-based positioning maps consider the similarities and differences between the different sites at the factor level. Such an analysis, therefore, lacks diagnostic information with respect to the contribution of the various characteristics to these positioning differences.

To address the first missing piece in the puzzle (that is the proximity of consumer ideal preferences to their perceptions of the e-retailer), an ideal vector that represents the relative effect of each of two factors on the desired positioning of an ideal internet shopping site was identified. This was done by regressing the relevant factor scores against consumer preferences for the different internet shopping sites, as per the method proposed by Urban and Hauser. ${ }^{41}$ This vector can be viewed as the ideal combination of both factors that consumers will prefer when making online purchases from a specific e-retailer. The closer the position of a specific e-retailer to this ideal vector, the closer it is to what consumers prefer.

The second missing piece (ie how to obtain the desired diagnostic information regarding the similarities and differences among the perceived characteristics of the different e-retailers) was addressed by conducting a perceptual gap analysis of the characteristics comprising each factor. This allowed those characteristics that might have contributed the most to the perceptual discrimination at the positioning map level between the 


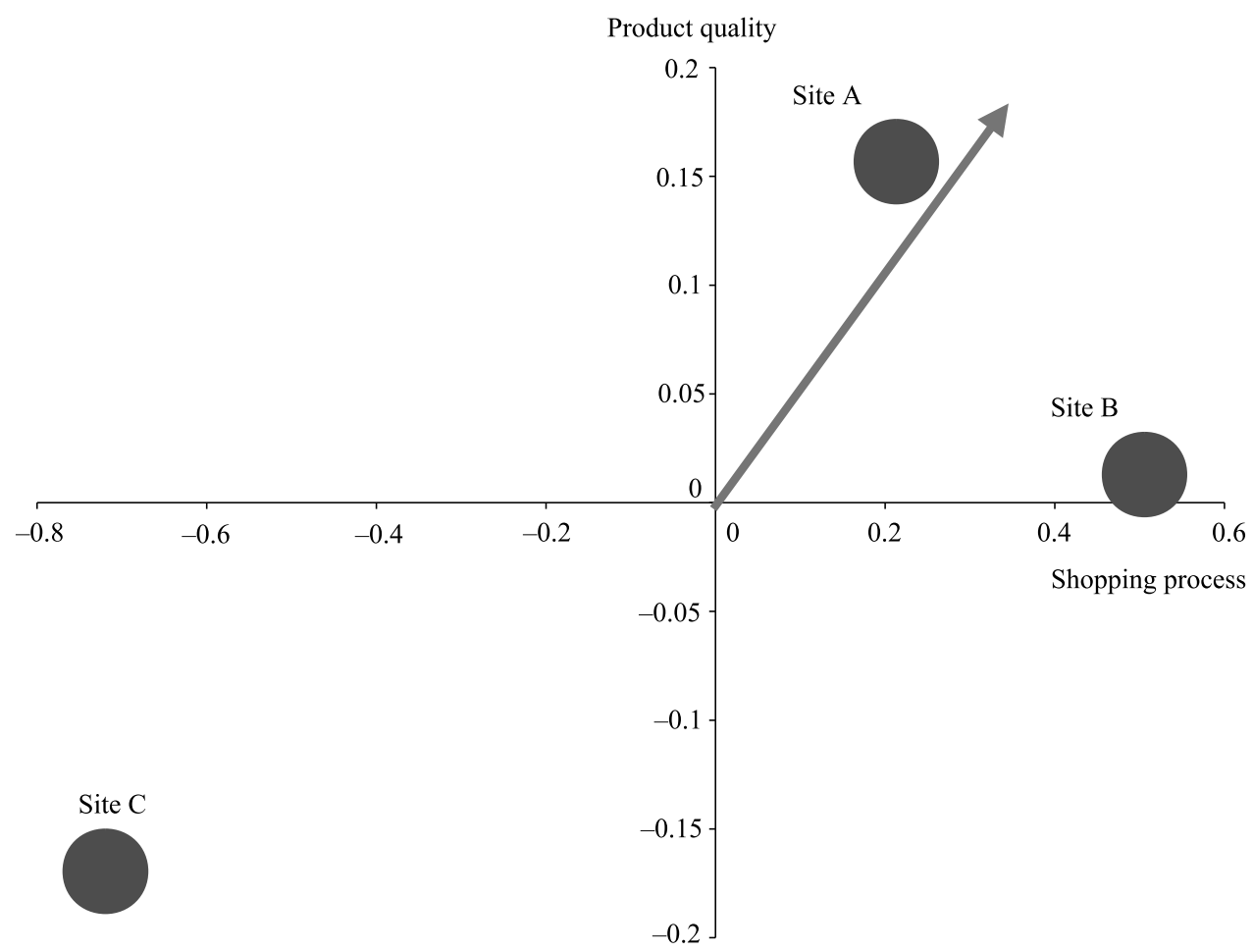

Figure 1A Positioning map for bookstores - Product quality vs shopping process

various internet shopping sites to be teased out.

\section{RESULTS}

The analyses are presented first for the bookstore e-retailers and then for the computer hardware e-retailers.

\section{Bookstore results}

\section{Positioning maps at the factor level}

Using principal component analysis, four factors with eigenvalues greater than 1 were extracted from the participant evaluations of the bookstores. The four factors, which explained 63 per cent of the variance (see Table 2), can further be used to construct the positioning maps. For expository purposes, only the first three factors are used and two factors at a time mapped. In Figures 1A, 1B and 1C the perceptual positioning maps of the bookstores are presented. Naturally, similar representations can be made regarding the relations of each of the three factors with the fourth factor, but this will not be displayed here in the interest of space. In addition, one might contemplate a presentation of three factors at a time, but such a presentation is likely to hamper understanding of the results.

Figure $1 \mathrm{~A}$ presents the location of the three e-retailers (the black circles) and the ideal positioning vector with regard to the two first factors: shopping process and product quality. The figure clearly shows distinct consumer perceptions of the actual benefits from the two dimensions for the three internet shopping sites. While this suggests that the consumers distinguish among the stores, it can also be seen which store is 


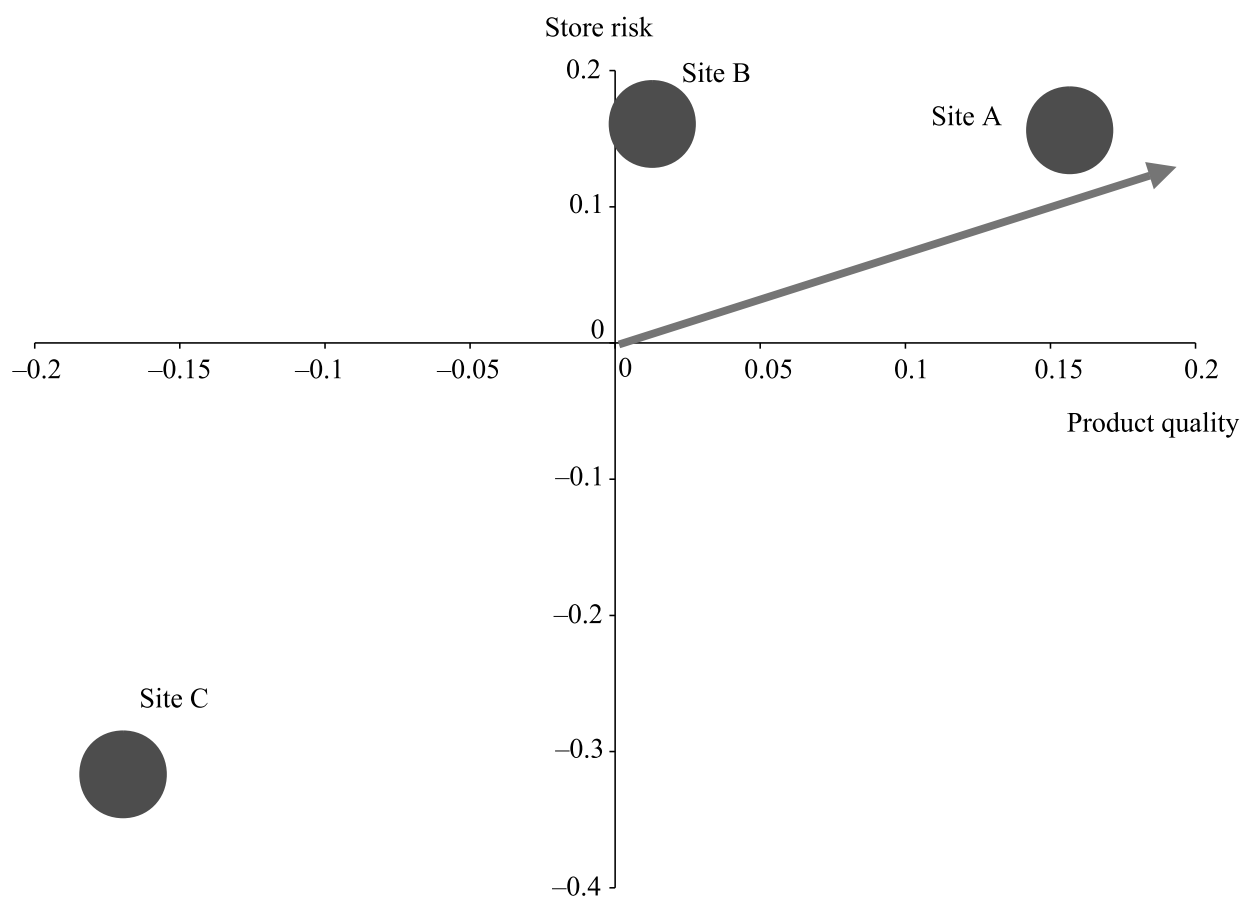

Figure 1B Positioning map for the bookstores - Store risk vs product quality

perceived as closer to the ideal vector that combines the two factors. When extracting the ideal vector, the following significant linear regression results were obtained: $\hat{y}=1.321 F 1+0.7 F 2$ with $\mathrm{R}^{2}=57.8 \%$. (For expository purposes the factors' coefficients only are presented, leaving out the constant). The construction of the ideal vector was carried out by regressing the overall preference for shopping from an internet site against the factor scores of the relevant two dimensions. The ratio of the estimated coefficients determined the slope of the vector. ${ }^{42}$ Using F1 and F2 coefficients, the ideal vector can be drawn and superimposed on the two-dimensional space of the first two factors (ie the arrow stretching from the origin of the axes in Figure 1A). This facilitates better insights as to the preference of consumers for an ideal combination of product quality and shopping process. Thus, the closer (in terms of Euclidean distance) the position of a given e-retailer to this vector, the closer the e-retailer is to the position consumers view as ideal.

Based on this analysis, one can see that site $\mathrm{A}$ is the closest to the ideal vector, indicating that this e-vendor is considered to be the best in terms of addressing consumer preferences with respect to the combination of ease of the shopping process and the quality of products offered by an e-retailer. It can also be seen that site $\mathrm{C}$ at its present state is far from fulfilling consumer preferences. The marketing implications of these results are elaborated on in the following section.

In a similar fashion the positioning map and the ideal vector for the combination of the store risk and the product quality factors were constructed (Figure 1B). The coefficients obtained for the ideal vector by the regression analysis were: $\hat{y}=0.7 F 2+0.468 F 3$ with 


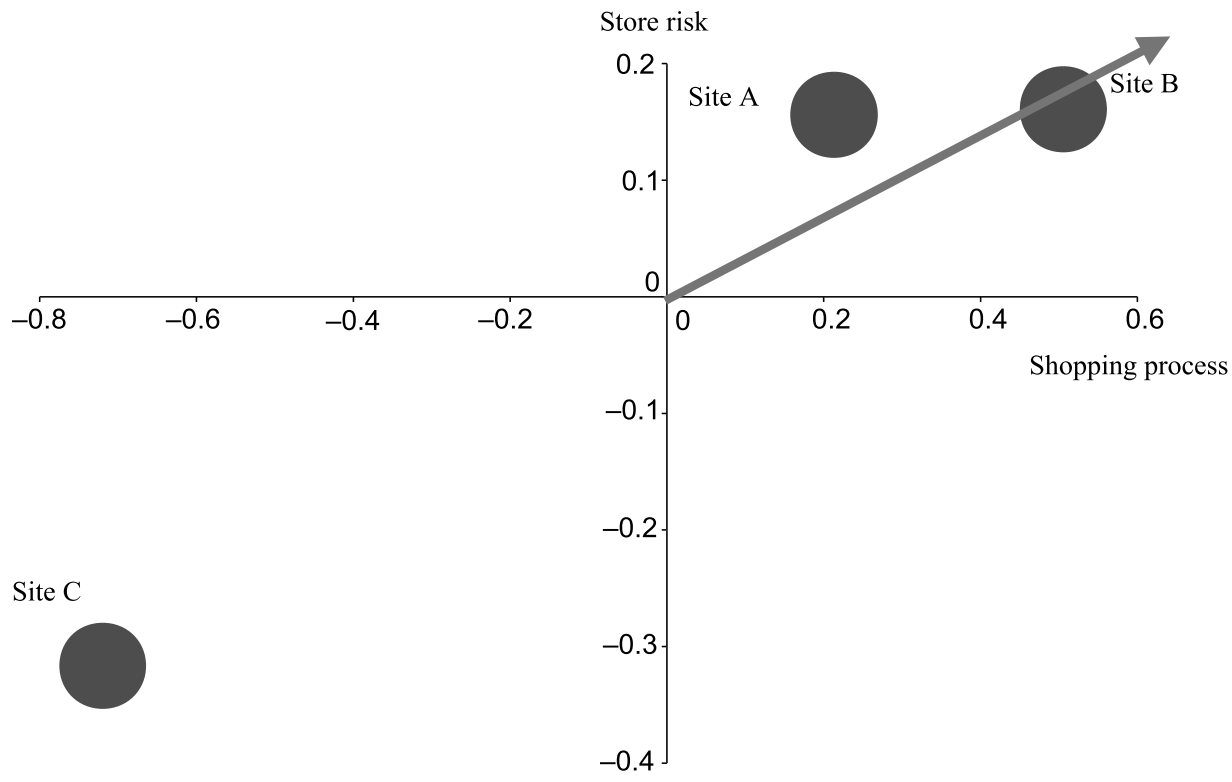

Figure 1C Positioning map for bookstores - Shopping process vs store risk

$\mathrm{R}^{2}=50.8 \%$. This map entails implications that are similar to the previous analysis. That is, site $\mathrm{A}$ is the closest to the ideal vector, and consumers still perceived the three sites to be distinct one from another, on the basis of the product quality and the risk involved in purchasing from the e-vendor.

Finally, the positioning map for the combination of store risk and the shopping process is presented in Figure $1 \mathrm{C}$. The result of the regression analysis for these factors explained 18.4 per cent of the variation with ideal factor's coefficients of $\hat{y}=1.321 F 1+0.468 F 3$. The results, however, deviate from the pattern of the previous two cases.

Namely, for this combination of factors site $\mathrm{B}$ addresses consumer preferences better than site A. Site $C$ is yet again the most distant from the ideal factor.

Perceptual gap analysis at the site characteristic level

The positioning maps helped tease out perceptual differences at the factor level (ie the more general level). To analyse the differences at the site-characteristic level (ie a more specific level), a perceptual gap analysis was conducted within each of the four factors that portray an e-retailer in the bookstore market.

The first factor, the shopping process is addressed first. In Figure $2 \mathrm{~A}$ a snake plot of consumer perceptions of the specific characteristics of the product quality factor is presented. The lines in Figure 2A represent the three e-retailers in the bookstore market. The various characteristics that comprise factor 1 are plotted on the $\mathrm{Y}$ axis, and the values on the abscissa reflect the perceptual attribute ratings of the various characteristics.

The perceptual gap analysis vividly demonstrates the intricate differences in consumer perceptions of the three sites, while at the same time providing a more general picture of these perceptions. Thus, it can be clearly seen that consumers perceived site $\mathrm{A}$ and site $\mathrm{B}$ to 


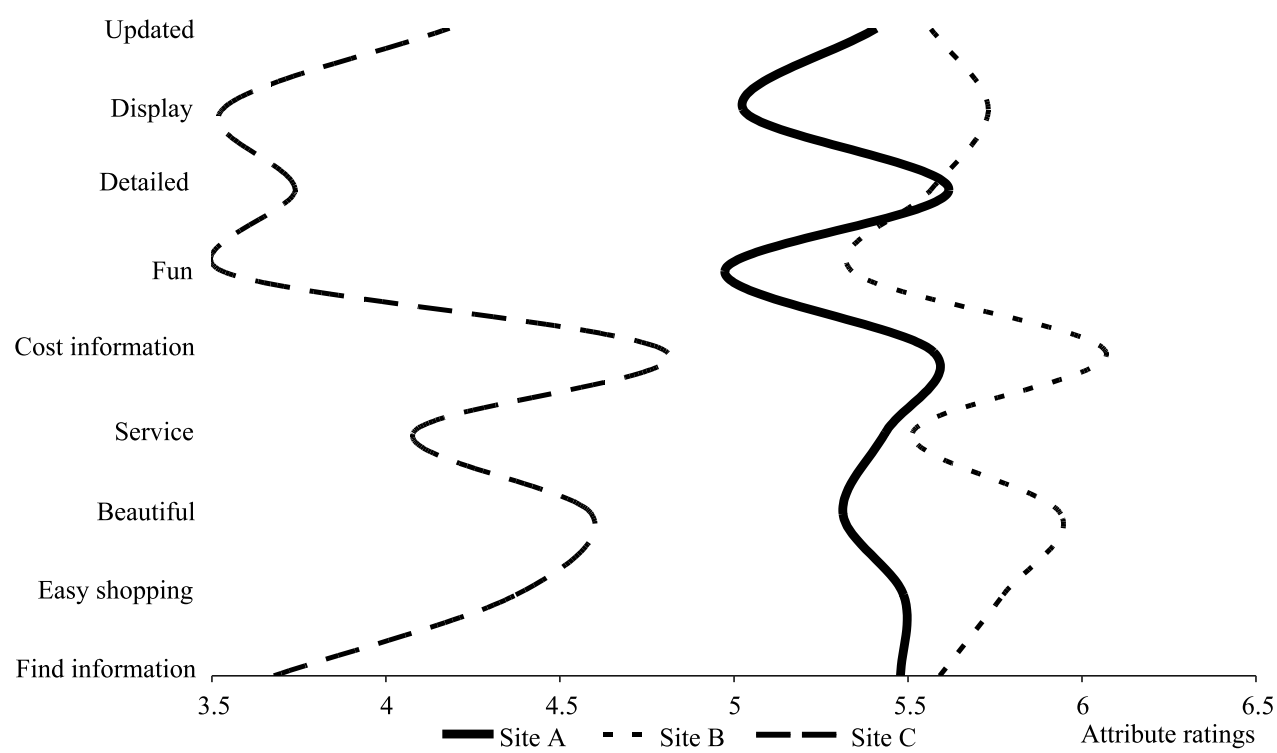

Figure 2A Perceptual gap analysis for the bookstores, factor 1 - Shopping process

be rather close to one another, while both are very different from site C.

Whereas Figure 2A presents a descriptive outline of consumer perceptions, the perceptual differences of the various stores can also be statistically tested for each characteristic of the product quality factor. Thus, the results of an ANOVA analysis of the attribute ratings are presented in Table 4A.

The combination of the ANOVA and the perceptual map provides a comprehensive picture of differences between the three sites. While sites A and $\mathrm{B}$ are different from site $\mathrm{C}$, site $\mathrm{B}$ has higher attribute ratings on being more beautiful, lower cost of information and a better display. These analyses can serve e-retailers in making more informed decisions regarding what changes should be made to their sites in order to improve how they are perceived by consumers, to close the perceptual gaps if necessary, and to get closer to the ideal vector.

Next the second factor in the book category was analysed. Figure 2B shows the snake plot of consumer perceptions of the characteristics that comprise the product quality factor.

Similarly to Figure 2A, consumer perceptions of sites $\mathrm{A}$ and $\mathrm{B}$ are quite similar, while perceptions of both are different from perceptions of site $\mathrm{C}$. Again, ANOVA on the attribute ratings determined the statistical significance of the perceptual differences between e-retailers at the characteristic level of the product quality factor. The ANOVA results are presented in Table 4B.

It can be seen that consumers had no perceptual discrimination between site $A$ and site $\mathrm{B}$ on any of the characteristics for Factor 2. They did, however, fully discriminate between these two sites and site C.

To conclude this analysis, a similar type of analysis was conducted for factor 3 , store risk. The results are presented in Figure 2C and Table 4C.

Analysing the results of this step, it can be seen that again, sites $\mathrm{A}$ and $\mathrm{B}$ are 
Table 4A: Mean ratings and ANOVA results, bookstores, factor 1 (shopping process)

\begin{tabular}{lllll}
\hline Characteristic & Site A & Site B & Site C & Significance level \\
\hline Find information & $5.48^{\mathrm{a}}$ & $5.59^{\mathrm{a}}$ & $3.68^{\mathrm{b}}$ & 0.000 \\
Easy shopping & $5.49^{\mathrm{a}}$ & $5.77^{\mathrm{a}}$ & $4.37^{\mathrm{b}}$ & 0.000 \\
Beautiful & $5.32^{\mathrm{b}}$ & $5.94^{\mathrm{a}}$ & $4.59^{\mathrm{c}}$ & 0.000 \\
Service & $5.46^{\mathrm{a}}$ & $5.52^{\mathrm{a}}$ & $4.08^{\mathrm{b}}$ & 0.000 \\
Cost information & $5.57^{\mathrm{b}}$ & $6.07^{\mathrm{a}}$ & $4.81^{\mathrm{c}}$ & 0.000 \\
Fun & $4.97^{\mathrm{a}}$ & $5.34^{\mathrm{a}}$ & $3.53^{\mathrm{a}}$ & 0.000 \\
Detailed & $5.6^{2 \mathrm{a}}$ & $5.56^{\mathrm{a}}$ & $3.74^{\mathrm{b}}$ & 0.000 \\
Display & $5.03^{\mathrm{b}}$ & $5.73^{\mathrm{a}}$ & $3.53^{\mathrm{c}}$ & 0.000 \\
Updated & $5.41^{\mathrm{a}}$ & $5.56^{\mathrm{a}}$ & $4.18^{\mathrm{b}}$ & 0.000 \\
\hline
\end{tabular}

Key: a, b, c - The superscripts in the table cells represent the order of the mean value of the perception of an attribute for the three sites such that ' $a$ ' denotes a mean value that is significantly $(p<0.05)$ greater than 'b'. 'b,' in turn, is significantly greater than ' $c$ '. Whenever two sites are represented by the same letter, there is no significant perceptual difference between those sites on that attribute.

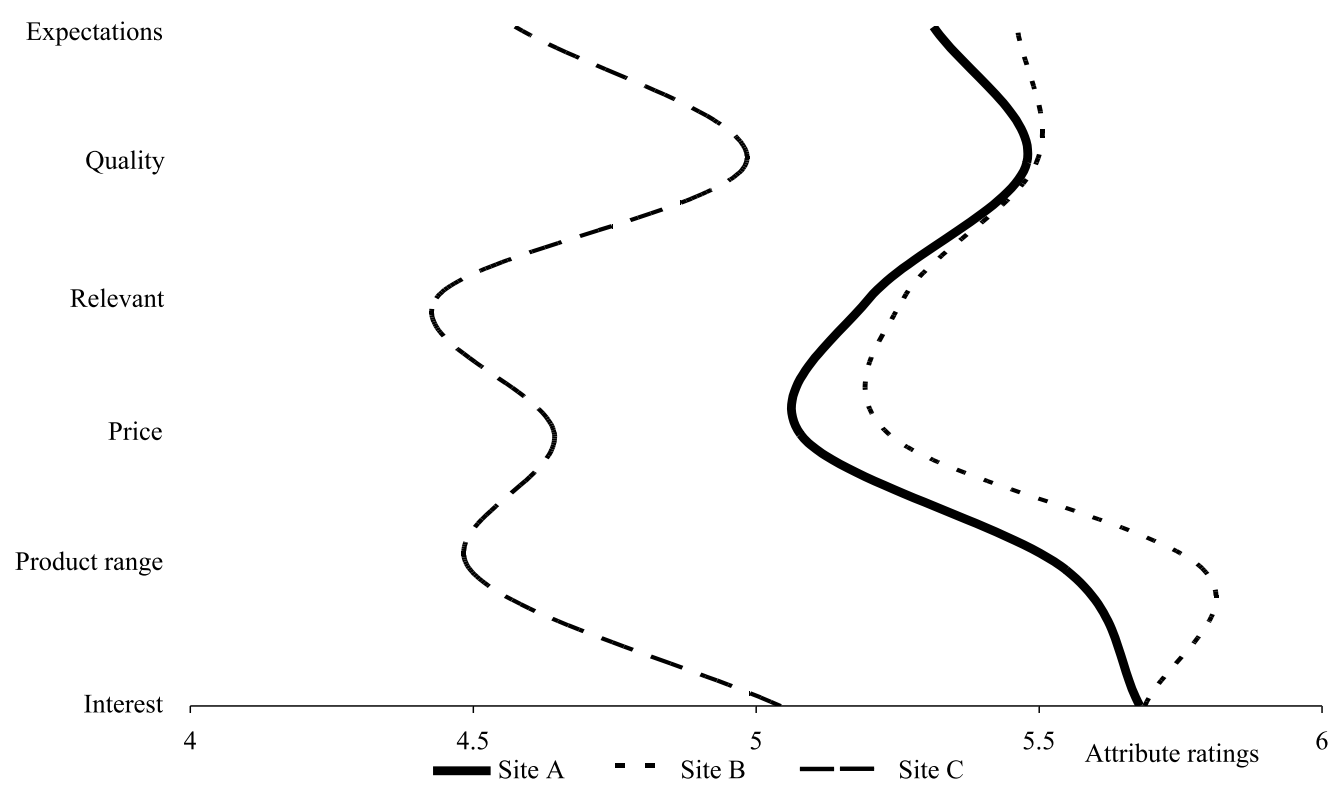

Figure 2B Perceptual gap analysis for the bookstores, factor 2 - Product quality

different from site $\mathrm{C}$ on three of the four characteristics, with the sole exception being that all e-retailers are conceived as equally likely to cause monetary losses to the users.

\section{Computer hardware results}

The previous subsection elaborated on the use of positioning maps and perceptual gap analysis for identifying the competitive positioning of e-retailers in the bookstore market. In this section the same analysis tools are used to examine the competitive positioning of e-retailers in the computer hardware market. In the interest of space, the findings of the analysis are presented in a more condensed form than the previous subsection. Assuming that the reader has by now been acquainted with the principles of the analysis tools, the results are presented and allowed to speak for themselves. The reader's attention is, however, drawn to the different determinant of the competitive field in the computer hardware industry relative to the bookstore industry (as mentioned 
Table 4B: Mean ratings and ANOVA results, bookstores, factor 2 (product quality)

\begin{tabular}{lllll}
\hline Characteristic & Site A & Site B & Site C & Significance level \\
\hline Interest & $5.68^{\mathrm{a}}$ & $5.69^{\mathrm{a}}$ & $5.04^{\mathrm{b}}$ & 0.000 \\
Product range & $5.55^{\mathrm{a}}$ & $5.79^{\mathrm{a}}$ & $4.50^{\mathrm{b}}$ & 0.000 \\
Price & $5.08^{\mathrm{a}}$ & $5.24^{\mathrm{a}}$ & $4.64^{\mathrm{b}}$ & 0.001 \\
Reliable information & $5.20^{\mathrm{a}}$ & $5.26^{\mathrm{a}}$ & $4.44^{\mathrm{b}}$ & 0.000 \\
Quality & $5.58^{\mathrm{a}}$ & $5.50^{\mathrm{a}}$ & $4.98^{\mathrm{b}}$ & 0.000 \\
Expectations & $5.31^{\mathrm{a}}$ & $5.46^{\mathrm{a}}$ & $4.57^{\mathrm{b}}$ & 0.000 \\
\hline
\end{tabular}

Key: $a, b-$ The superscripts in the table cells represent the order of the mean value of the perception of an attribute for the three sites such that ' $a$ ' denotes a mean value that is significantly $(p<0.05)$ greater than ' $b$ '. Whenever two sites are represented by the same letter, there is no significant perceptual difference between those sites on that attribute.

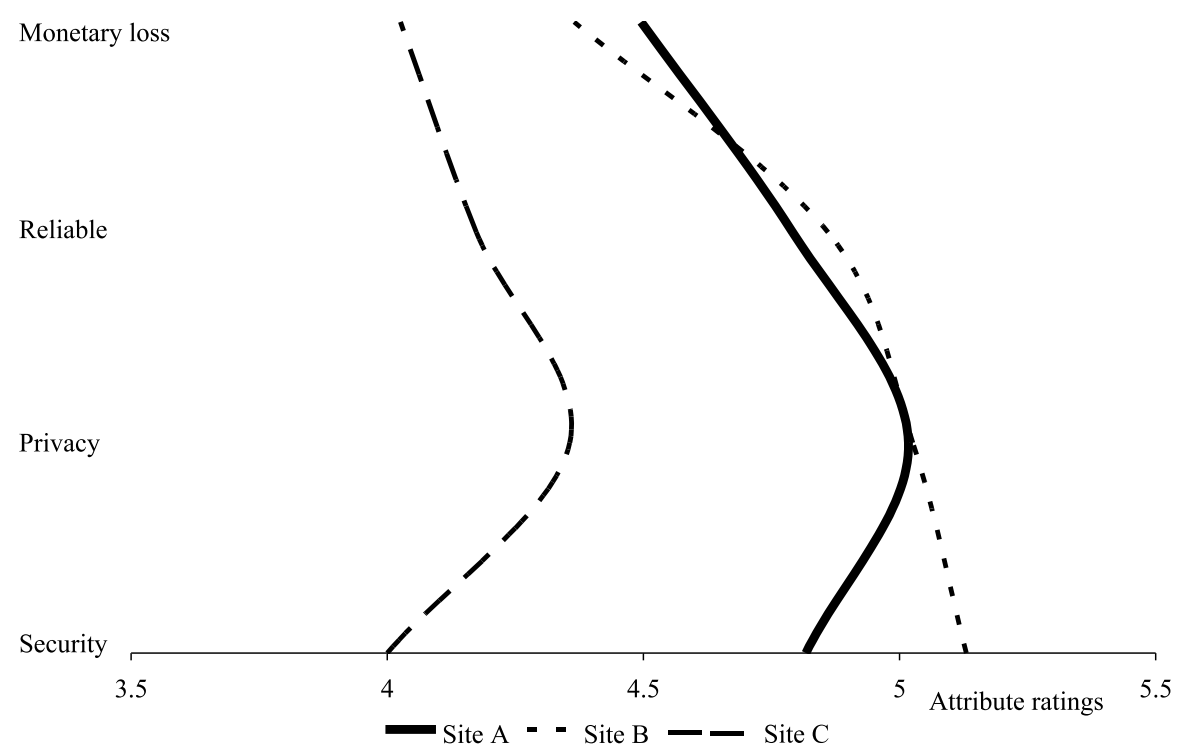

Figure 2C Perceptual gap analysis for the bookstores, factor 3 - Store risk

in the 'Method' section, under

'Database') and to the different competitive balance between the e-retailers, as these are revealed by the analysis tools. The marketing implications of the two e-retail environments will be discussed in further detail below under 'Marketing implications'.

\section{Positioning maps at the factor level}

As in the previous set of analyses of the book category, the starting point is three positioning maps of the three internet shopping sites. As was mentioned in the Method section, six factors having an eigenvalue greater than one were extracted from the data on computer stores. The factors explained more than 66 per cent of the variance (see Table 3) and were used to construct the positioning maps. Again, since the primary concern here is with demonstrating the usefulness of the approach rather than with in-depth analysis of specific sites, the ensuing analyses refer only to the first three factors. Similarly, for expository purposes two factors at a time are mapped. Figures $3 \mathrm{~A}, 3 \mathrm{~B}$ and $3 \mathrm{C}$ present the perceptual positioning maps of the computer stores.

Figure 3A suggests that each of the three internet shopping sites has a 
Table 4C: Mean ratings and ANOVA results, bookstores, factor 3 (store risk)

\begin{tabular}{lllll}
\hline Characteristic & Site A & Site B & Site C & Significance level \\
\hline Security & $4.82^{\mathrm{a}}$ & $5.13^{\mathrm{a}}$ & $4.00^{\mathrm{b}}$ & 0.000 \\
Privacy & $5.02^{\mathrm{a}}$ & $5.03^{\mathrm{a}}$ & $4.36^{\mathrm{b}}$ & 0.000 \\
Reliable & $4.79^{\mathrm{a}}$ & $4.86^{\mathrm{a}}$ & $4.17^{\mathrm{b}}$ & 0.000 \\
Monetary loss & $4.50^{\mathrm{a}}$ & $4.37^{\mathrm{a}}$ & $4.03^{\mathrm{a}}$ & 0.056 \\
\hline
\end{tabular}

Key: $a, b-$ The superscripts in the table cells represent the order of the mean value of the perception of an attribute for the three sites such that ' $a$ ' denotes a mean value that is significantly $(p<0.05)$ greater than ' $b$ '. Whenever two sites are represented by the same letter, there is no significant perceptual difference between those sites on that attribute.

distinct positioning. That is, consumers perceptually discriminate between the three e-retailers regarding the two dimensions. For the ideal factor, the following significant linear regression results were obtained:

$\hat{y}=0.858 F+0.797 F 2$, with $\mathrm{R}^{2}=38.8 \%$.

This analysis indicates that none of the stores is very close to the ideal vector. That is, the offerings of the current sites are not exactly in keeping with consumer preferences. Nevertheless, site $\mathrm{A}$ is the least distant from the ideal vector and, therefore, is closer to addressing consumer preferences with respect to the ease of the shopping process and the quality of information in purchasing from that store.

For the two dimensions in Figure 3B, it seems that site $\mathrm{A}$ is much closer to the ideal vector (ie $\hat{y}=0.797 F 2+0.427 F 3$, with $\mathrm{R}^{2}=26 \%$ ) than the other two sites.

As in Figure 3A, it can be seen in Figure $3 \mathrm{C}$ that the three sites do not address consumer preferences with respect to the ease of shopping process and the quality of information they require. The positions of all three sites are quite distant from the ideal vector (ie $\hat{y}=0.858 F 1+0.427 F 3$ with $\mathrm{R}^{2}=23.1 \%$ ).

In short, it appears that these three e-retailers in the computer hardware domain were far from fully addressing consumer preferences with respect to the ease of shopping process and quality of information. The marketing implications for managers in such stores are discussed in the following section.

\section{Perceptual gap analysis at the site characteristic level}

As was the case with the bookstores, perceptual gaps between the three computer hardware sites were further analysed in an attempt to refine the recommendations regarding the changes that have to be made in the three stores. The starting point is a gap analysis of the characteristics comprising first factor, as presented in Figure 4A, and it is complemented with ANOVA analysis, as presented in Table 5A.

The analysis of factor 1 in Figure 4A and Table 5A shows a distinct difference between sites B and C. Site A is evaluated as somewhat 'in between' the other sites. That is, it is similar to both sites ( $\mathrm{A}$ and $\mathrm{B}$ ) with respect to the ease of finding information, ease of shopping and the level of service. It is, however, similar to site B in terms of the beauty of its design and appealing display, and similar to site $\mathrm{C}$ in terms of how fun the shopping experience is.

All three sites are very similar in terms of factor 2, as can be seen in Figure 4B and Table 5B. The exception to this is the difference between site $\mathrm{B}$ and site $\mathrm{C}$ on the attribute of information about product costs. In other words, there is very little differentiation between the three sites on this factor.

Similar to the results obtained for 


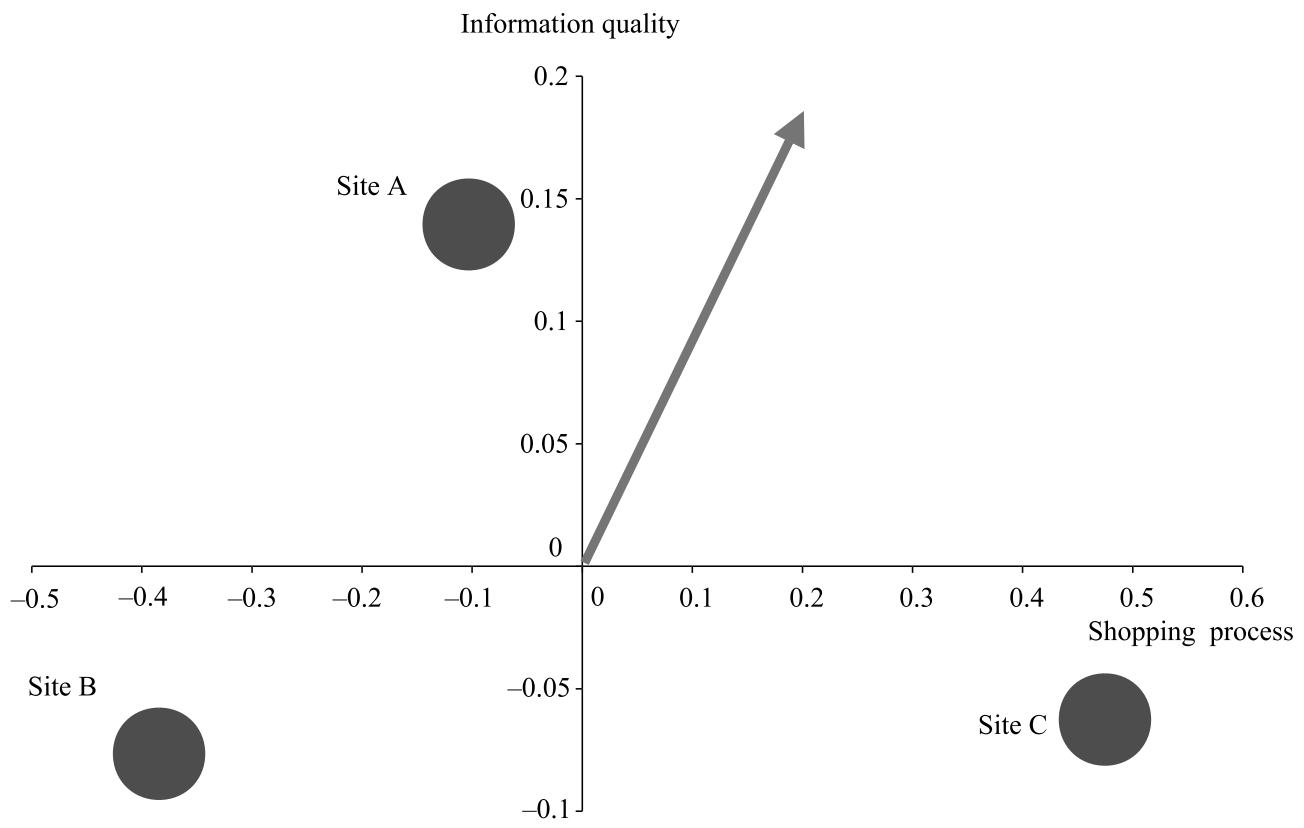

Figure 3A Positioning map for the computer hardware stores - Shopping process vs information quality

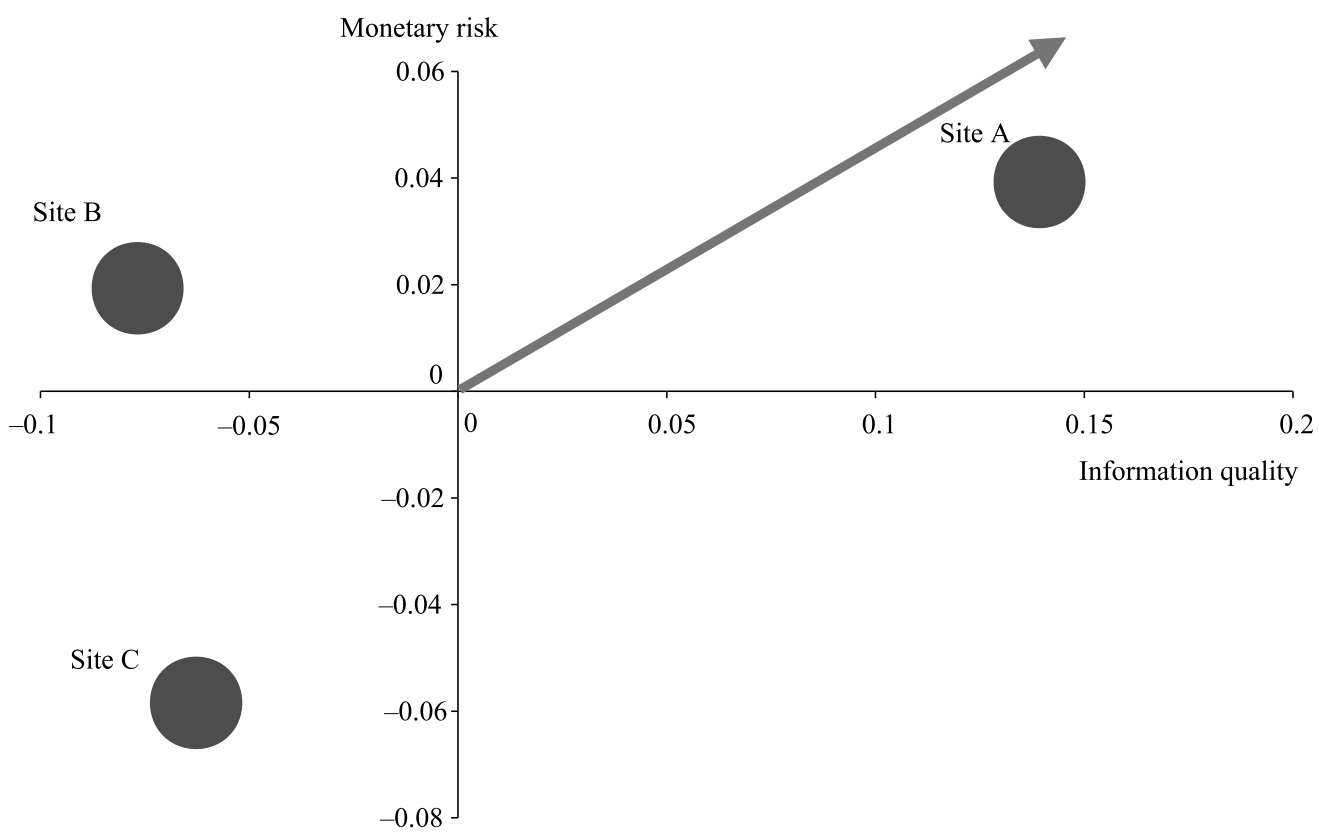

Figure 3B Positioning map for the computer hardware stores - Information quality vs monetary risk 


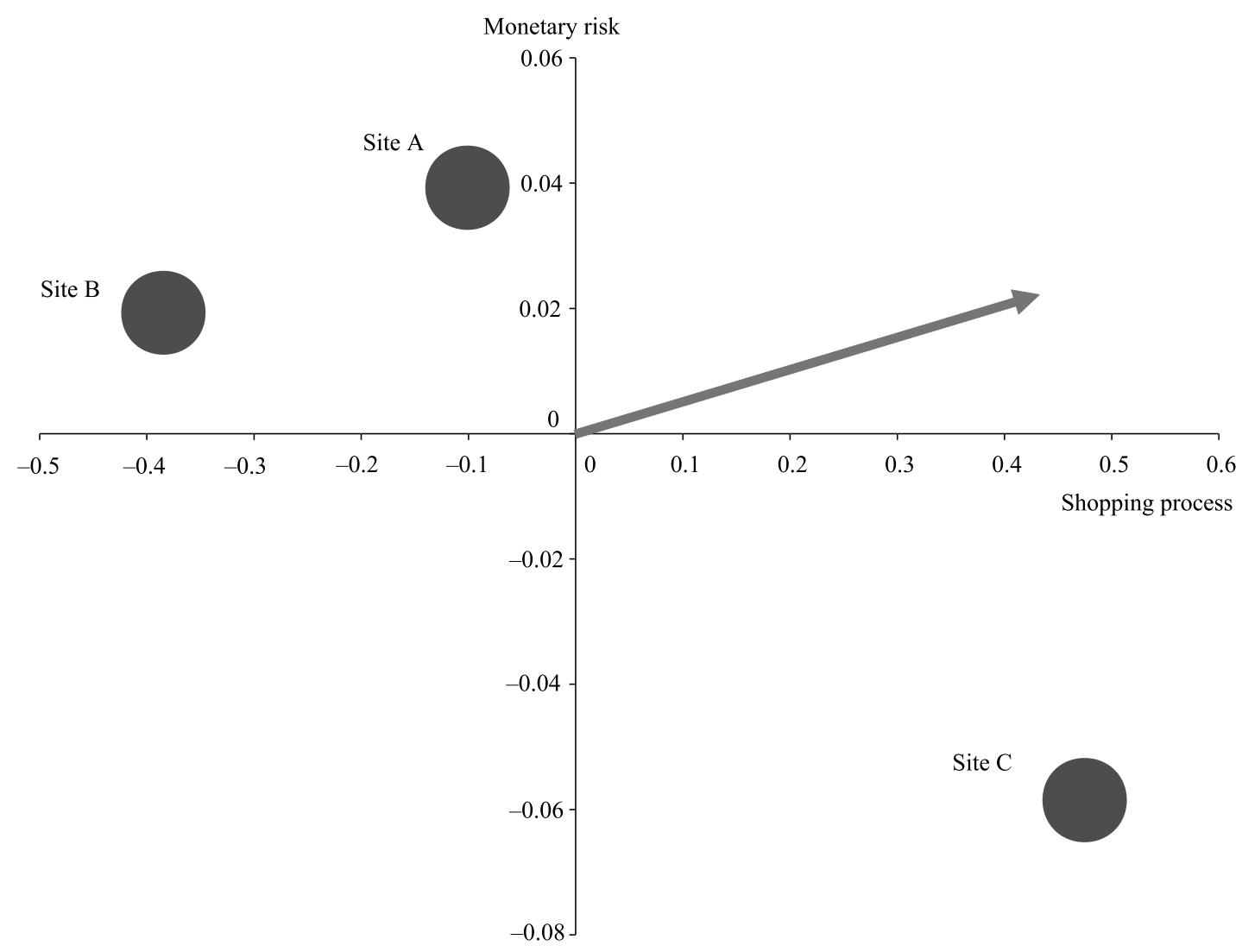

Figure 3C Positioning map for the computer hardware stores - Shopping process vs monetary risk

Table 5A: ANOVA results, computer hardware stores, factor 1 (shopping process)

\begin{tabular}{lllll}
\hline Characteristic & Site A & Site B & Site C & Significant level \\
\hline Find information & $5.14^{\mathrm{ab}}$ & $4.89^{\mathrm{b}}$ & $5.44^{\mathrm{a}}$ & 0.033 \\
Easy shopping & $5.11^{\mathrm{ab}}$ & $4.41^{\mathrm{b}}$ & $5.25^{\mathrm{a}}$ & 0.000 \\
Beautiful & $4.57^{\mathrm{b}}$ & $4.35^{\mathrm{b}}$ & $5.78^{\mathrm{a}}$ & 0.000 \\
Service & $4.66^{\mathrm{ab}}$ & 4.22 & $4.85^{\mathrm{a}}$ & 0.004 \\
Fun & $4.31^{\mathrm{a}}$ & $3.77^{\mathrm{b}}$ & $4.75^{\mathrm{a}}$ & 0.000 \\
Display & $4.30^{\mathrm{b}}$ & $4.12^{\mathrm{b}}$ & $5.02^{\mathrm{a}}$ & 0.000 \\
\hline
\end{tabular}

Key: $a, b-$ The superscripts in the table cells represent the order of the mean value of the perception of an attribute for the three sites such that ' $a$ ' denotes a mean value that is significantly $(p<0.05)$ greater than ' $b$ '. Whenever two sites are represented by the same letter, there is no significant perceptual difference between those sites on that attribute. 'ab' indicates that the mean attribute value of a site for a specific attribute is not significantly different from the other two sites, ' $a$ ' and ' $b$ ', but the latter two are significantly different from each other.

Factor 2, it can be seen that there is very little differentiation between the three sites on the characteristics comprising Factor 3, as depicted by Figure 4C and Table 5C.

\section{MARKETING IMPLICATIONS}

The set of analyses suggested and demonstrated in this study can help e-retailers understand and improve their position in the volatile and competitive 


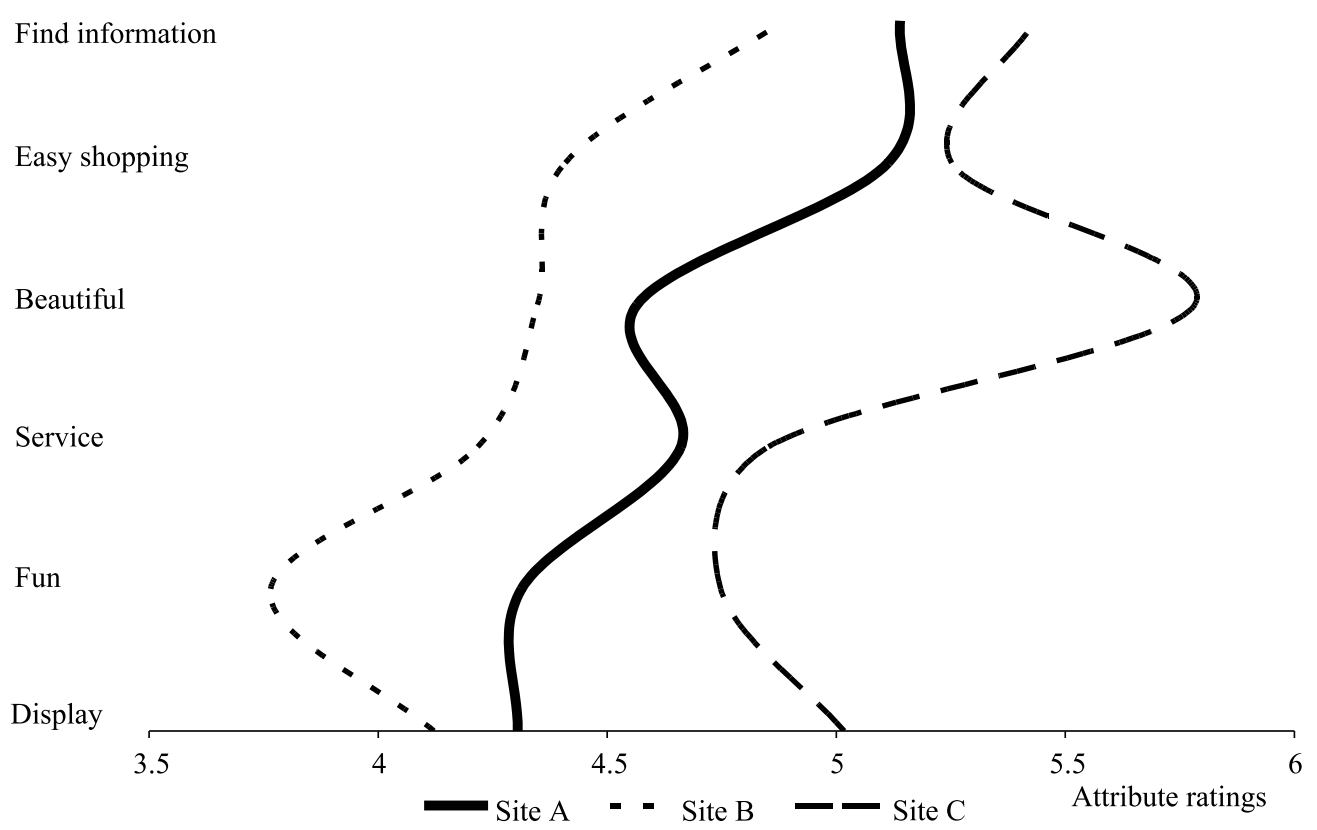

Figure 4A Perceptual gap analysis for the computer hardware stores, factor 1 - Shopping process

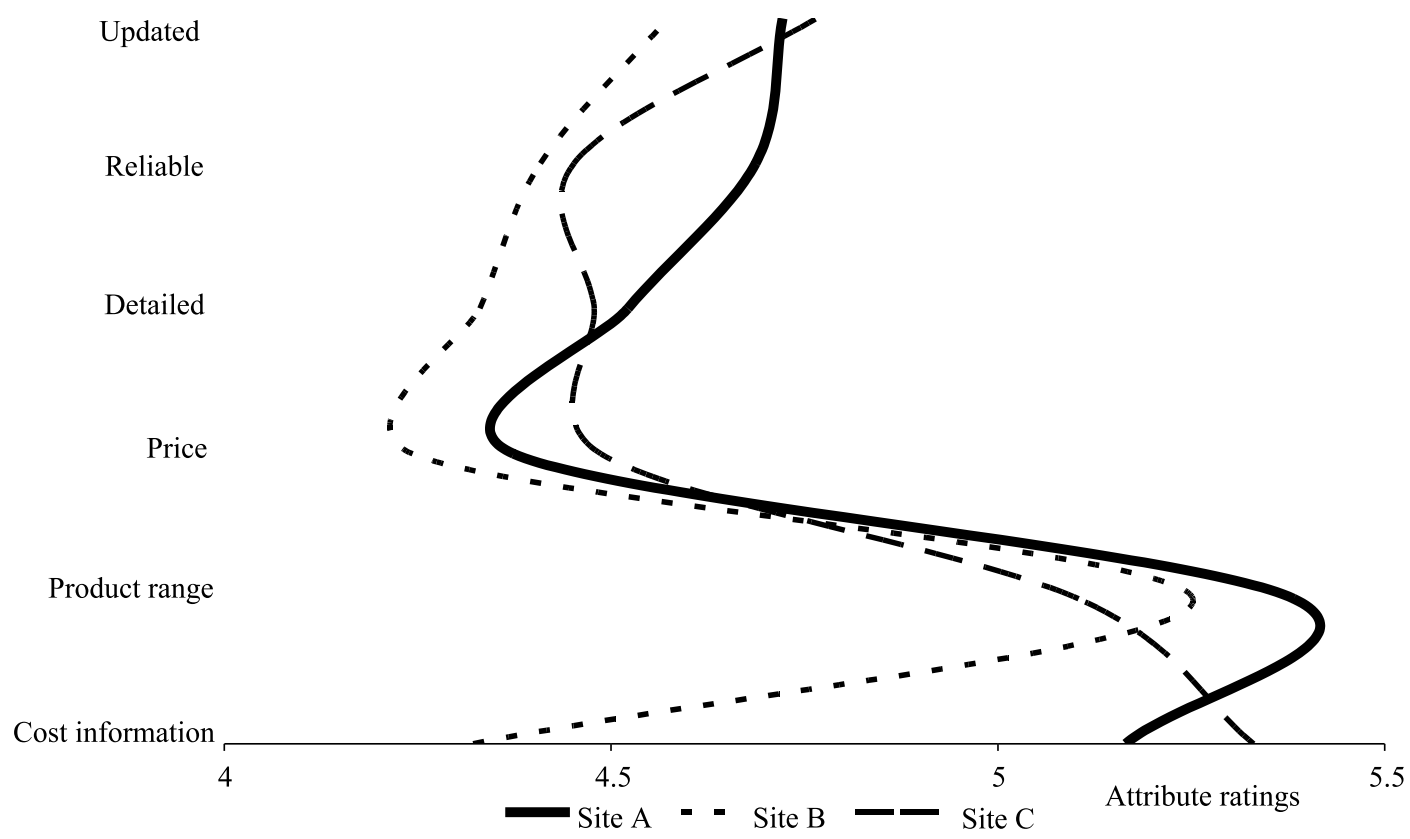

Figure 4B Perceptual gap analysis for the computer hardware stores, factor 2 - Quality of product information 
Table 5B: ANOVA results, factor 2, computer category (quality of product information)

\begin{tabular}{lllll}
\hline Characteristic & Site A & Site B & Site C & Significant level \\
\hline Cost information & $5.17^{\mathrm{a}}$ & $4.32^{\mathrm{b}}$ & $5.33^{\mathrm{a}}$ & 0.000 \\
Product range & $5.38^{\mathrm{a}}$ & $5.25^{\mathrm{a}}$ & $5.10^{\mathrm{a}}$ & 0.360 \\
Price & $4.37^{\mathrm{a}}$ & $4.24^{\mathrm{a}}$ & $4.49^{\mathrm{a}}$ & 0.398 \\
Detailed & $4.52^{\mathrm{a}}$ & $4.33^{\mathrm{a}}$ & $4.48^{\mathrm{a}}$ & 0.675 \\
Reliable information & $4.69^{\mathrm{a}}$ & $4.41^{\mathrm{a}}$ & $4.45^{\mathrm{a}}$ & 0.225 \\
Updated & $4.72^{\mathrm{a}}$ & $4.57^{\mathrm{a}}$ & $4.77^{\mathrm{a}}$ & 0.000 \\
\hline
\end{tabular}

Key: $a, b-$ The superscripts in the table cells represent the order of the mean value of the perception of an attribute for the three sites such that ' $a$ ' denotes a mean value that is significantly $(p<0.05)$ greater than ' $b$ '. Whenever two sites are represented by the same letter, there is no significant perceptual difference between those sites on that attribute.

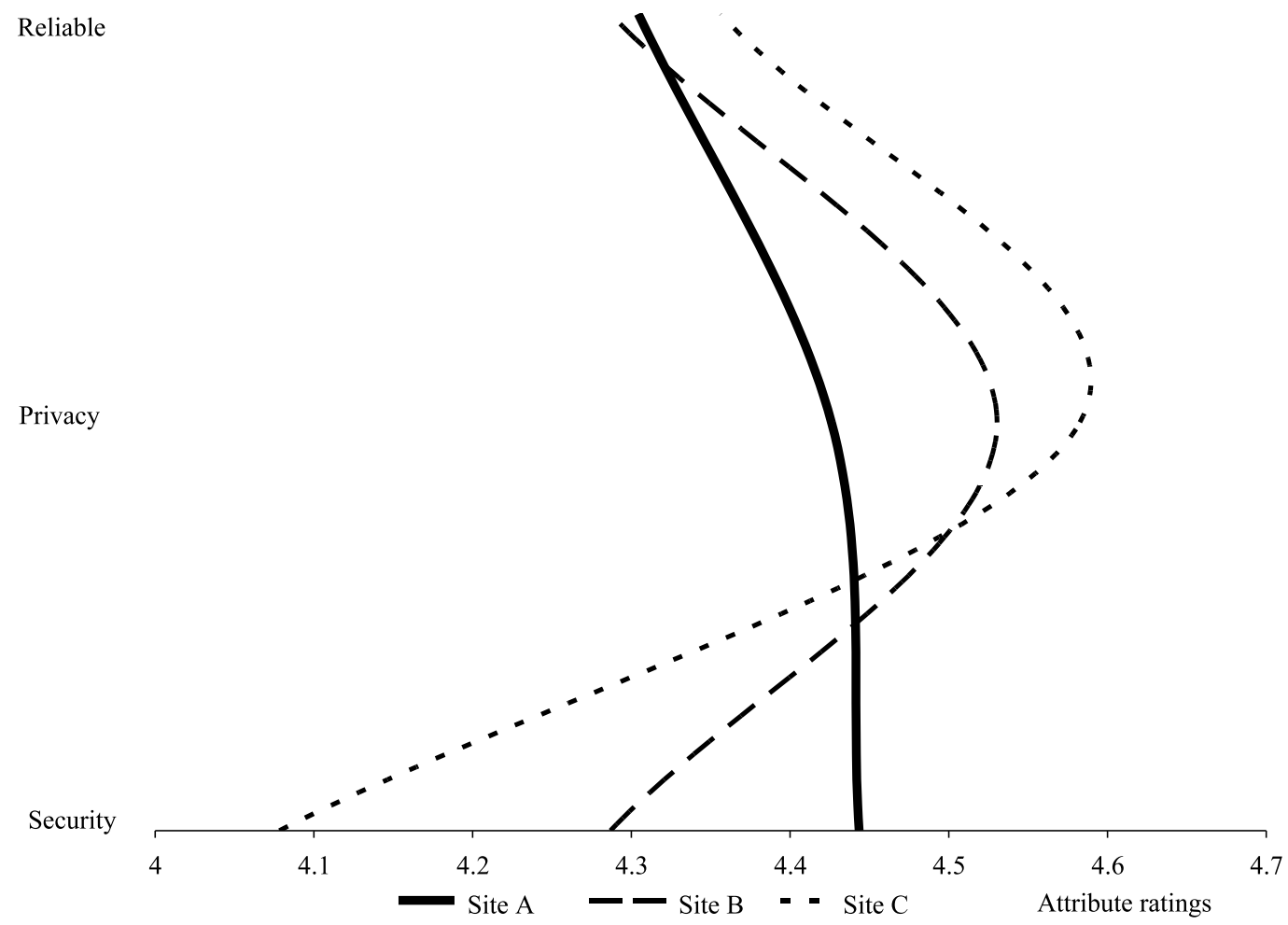

Figure 4C Perceptual gap analysis for the computer hardware stores, factor 3 - Monetary risks

environment within which they operate. In this section the type of marketing implications that e-retailers can draw from this set of analyses are demonstrated. Most importantly, these implications relate to changing consumer perceptions about the various characteristics of internet shopping sites. Since consumer perceptions and attitudes form their preferences, improving perceptions are likely to lead to more favourable preferences toward the web-based store. Changes in perceived store characteristics can stem from: (1) a 'real' change, ie a change in the essence of the characteristic (eg the e-store provides more information about the cost of the goods sold on the site); or (2) an apparent change, ie a change that stems from the appearance of the e-retailer's 
Table 5C: ANOVA results, factor 3, computer category (monetary risk)

\begin{tabular}{lllll}
\hline Characteristic & Site A & Site $\mathbf{B}^{\mathbf{2}}$ & Site $\mathbf{C}^{\mathbf{3}}$ & Significance level $^{\mathbf{4}}$ \\
\hline Security & $4.443^{\mathrm{a}}$ & $4.287^{\mathrm{a}}$ & $4.078^{\mathrm{a}}$ & 0.089 \\
Privacy & $4.426^{\mathrm{a}}$ & $4.530^{\mathrm{a}}$ & $4.583^{\mathrm{a}}$ & 0.627 \\
Reliable & $4.304^{\mathrm{a}}$ & $4.287^{\mathrm{a}}$ & $4.357^{\mathrm{a}}$ & 0.225 \\
\hline
\end{tabular}

Key: a - There is no significant perceptual difference between the sites

website. For example, the website may state 'we now have a secured payment procedure' even if it used such procedure in the past but its existence was not conveyed to consumers properly before. The new statement might change how potential customers view the site, although the site has essentially remained unchanged. Since this study measured consumer perceptions about site characteristics (ie 'apparent characteristics'), this analysis points to which characteristics should be changed and in what direction, rather than indicating the exact form of how to change or what degree of a change is needed. For example, whether an improvement should be made with respect to the assortment the store carries can be indicated, but what the exact type of assortment should be cannot. This issue should be addressed by other methods that can examine the optimal assortment in an internet shopping site carrying books or computers.

\section{Bookstores}

The discussion of marketing implications for e-retailers begins with the bookstore category. Of the three web stores, site A seems to be the closest, in general, to the ideal vector. Site $\mathrm{C}$ is the most distant. Analysing the results from Figures 2A, 2B and 2C and Tables 2, 4A, 4B, and $4 \mathrm{C}$ conclusions can be drawn as to the appropriate actions managers of the three internet shopping sites can take to improve their positioning. The first general implication is that most of the similarities and differences between sites $\mathrm{A}$ and $\mathrm{B}$ are rooted in the shopping process (ie factor 1).

Site $\mathrm{C}$ differs from the other sites on all factors. Another broad implication is that site B seems to be 'overshooting' with respect to the level of the characteristics comprising factor 1 . This conclusion is drawn from the proximity of site $\mathrm{A}$ to the ideal vector in Figures $1 \mathrm{~A}$ and $1 \mathrm{~B}$, the position of site $\mathrm{A}$ plot in Figure 1A, and the values in Table 4A.

The more specific implications for each e-retailer, based on the perceptual gap analyses, can be described as follows. Retailer A, while leading the pack in this three-site market, can still improve the shopping process on its site. Such improvements may include, for example, a better display of the products, making the shopping experience more fun, improving customer service and enhancing the visual appeal of the site. Similarly, it should also try to improve consumer perceptions of the security of the site. The expected changes in consumer perceptions regarding these characteristics would result in movement of site A toward the ideal vector with respect to the shopping process and the risk dimensions.

Retailer B may represent the 'more is less' phenomenon. It should consider cutting down on some of the characteristics that comprise factor 1 . In general, it appears that retailer B has been overloading its site with visual design features. It could be that 
consumers view sites that are too dense in terms of information displayed as well as sites that are overly coloured and sophisticated as barriers to a smooth shopping process. This could be a result of the specific product category at hand - books. That is, when purchasing a book, which is not an experiential product, consumers may appreciate an easy, quick shopping process. The aforementioned features of an internet shopping site are likely to increase the amount of time spent on the site. High levels of these characteristics, therefore, might impede the shopping process.

Of the three bookstores, e-retailer C stands out negatively. With the exception of a few characteristics, this site needs improvements across the board. Indeed, given the extremely undesirable location of site $\mathrm{C}$ on the positioning maps and the obvious gaps between its perceived characteristics and those of its competitors, its management should seriously consider a major overhaul of its website. Thus, it seems that the best course of action in this case would be a complete re-positioning of the site.

\section{Computer hardware stores}

The computer hardware e-retail market (as represented by the three sites examined in this study) is quite different from that of the bookstores. This was evident in the large distance between the three sites and the ideal vector. While site $\mathrm{A}$ and site $\mathrm{B}$ were close to the ideal vector in the bookstore market (ie Figures $1 \mathrm{~A}$ and $1 \mathrm{C}$ ), there is no such proximity in the computer category. The first general implications that can be drawn from this finding are that: (1) the e-retailers in the study were not properly addressing consumer needs; and (2) each site has room to adjust to the preferred combination of the various factors by changing its site characteristics and taking the lead in terms of being the first to close the gaps to the ideal vectors. Such a move could propel the e-retailer to market leadership, and thus command a higher market share as compared to the rival sites.

The second general implication that can be drawn from the analysis of the computer e-retailers is that major differences exist predominantly in the shopping process factor (ie factor 1) and to a much lesser degree on the information quality dimension (ie factor 2). This implies that an e-retailer concentrating on improving the shopping process along the relevant characteristics will substantially improve the competitive standing of that site.

Following these two general implications, some specific implications for the three computer hardware e-retailers can now be drawn. The position of e-retailer A with respect to the quality of information it provides is better than that of the other two sites, as can be seen from Figure 3B. This site can still improve its position by providing a better product range and reliable information. With respect to the shopping process, as in the books category, the site that was rated highest on the characteristics that comprise this factor is not positioned closer to the ideal vector. It implies that this site (ie site C) is 'overshooting' with the level of some of the characteristics that comprise this factor. But specific recommendations to e-retailer A would probably be that its site should improve by way of making it more beautiful, have a better display of the offerings and increase the fun of shopping in the site (see Figure 4A and Table 5A).

E-retailer B suffers from consumer perceptions about the characteristics that comprise the two first factors - the shopping process and the quality of the information provided by the site. It 
should, therefore, attempt to improve consumer perceptions on all of these characteristics. This will include: improving the visual attractiveness of the site; making the shopping process an easier and more fun experience; and improving the service and the display of the offerings (see Figure 4A and Table $5 \mathrm{~A})$. At the same time, site $\mathrm{B}$ would be substantially better off by improving consumer perceptions about cost information, as can be concluded from Figure 4B and Table 5B. Such an improvement would close the perceptual gap between site B and sites A and C with respect to this characteristic. The above-mentioned changes in consumer perceptions will eventually shift the positioning of site B from the lower left quadrant of Figure 3A toward the upper right quadrant.

As mentioned earlier, site $\mathrm{C}$ seems to be overshooting the preferences of its potential customers with the design of shopping process implemented on its website. It can be inferred from the analyses that in order to improve its competitive standing, it should undertake some major adjustments. The management of this site should reduce superfluous design elements among the characteristics that comprise factor 1 . Apparently, scaling down the levels of ornamental design could help bring the site to a better position as a computer hardware retailer. This will shift the positioning of this site closer to the ideal vector (ie Figure 3A).

\section{CONCLUSION}

Exploring the competitive positioning of internet shopping sites is of great importance for managers. As in traditional retailing, positioning entails how consumers view the competitive intensity between rival retail outlets. This study investigates positioning in the internet retailing environment, a context within which the concept of positioning has thus far gained only limited attention. The implementation of an analysis framework for the assessment of retailer position in its competitive environment has been suggested. The usefulness of this framework has been demonstrated in the context of internet retailing. This usefulness stems from the ability of managers to analyse their competitive position both on a high level (ie general factors) and on a low level (ie specific characteristics of each factor). In addition, the sensitivity of the analysis tools to the variations in the competitive environment has been shown. Thus, the differences in two different competitive e-retail environments such as the bookstore market and the computer hardware market were demonstrated in this study.

Obviously, the analyses presented in this paper to illustrate the effectiveness of the proposed methodological framework are bounded by the nature of the industries, the websites and the sample involved in the original data set. Yet, the authors believe that this is precisely the main strength and appeal of the study. It combines the offer of a generalised methodology, suitable for the entire gamut of e-retail domains, with the ability to analyse particular e-retail domains and to deduce site-specific implications and guidelines.

Thus, on the operational level, this study delivers new insights into the underlying dimensions of consumer evaluations of internet retailing sites as well as the competitive intensity of such markets. At the same time, the relationship between current consumer perceptions of various internet shopping sites on various dimensions and their preferred combination of those dimensions (ie their relative proximity to the ideal vector) has been shown. 
The framework proposed in this study can be augmented in various ways. For example, the analyses can be expanded to additional product categories and markets. This can create a continuum of product types and then assist in investigating the relationship between consumer perceptions and preferences along this continuum. Another endeavour can focus on exploring the dynamics of consumer perceptions of internet shopping sites. In a young and rapidly changing environment such as e-retailing, a 'standard' or 'acceptable' shopping site format has not been established yet. A longitudinal study that explores such changes in perceptions can shed more light on the reactions of e-retailers to changes in the environment and the corresponding changes in consumer perceptions and purchasing preferences.

\section{References}

1 Berthon, P., Holbrook, M. B. and Hulbert, J. M. (2000) 'Beyond market orientation: A conceptualization of market evolution', Journal of Interactive Marketing, Vol. 14, No. 3, pp. 50-66.

2 Ibid.

3 Patton, S. (2001) 'Staying power', CIO Magazine, 1st December,

http://www.cio.com/archive/120101/power.html.

4 Jarvenpaa, S. L. and Tractinsky, N. (1999)

'Consumer trust in an internet store: A cross-cultural validation', Journal of Computer-Mediated

Communication, Vol. 5, No. 2, available online:

http://www.ascusc.org/jcmc/vol5/issue2/.

5 Zhang, P. and von Dran, G. (2001) 'User expectations and ranks of quality factors in different website domains', International Journal of Electronic Commerce, Vol. 6, No. 3, Winter, pp. 9-34.

6 Zhang, P., von Dran, G., Blake, P. and Pipithsuksunt, V. (2001) 'Important design features in different website domains: An empirical study of user perceptions', e-Service Journal, Vol. 1, No. 1, pp. 77-91.

7 Li, H., Daugherty, T. and Riocca, F. (2001) 'Characteristics of virtual experience in electronic commerce: A protocol analysis', Journal of Interactive Marketing, Vol. 15, No. 3, pp. 13-30.

8 Emmanouilides, C. and Hammond, K. (2000) 'Internet usage: Predictors of active users and frequency of use', Journal of Interactive Marketing, Vol. 14, No. 2, pp. 17-32.
9 Lohse, G. L., Bellman, S. and Johnson, E. J. (2000) 'Consumer buying behavior on the internet: Findings from panel data', Journal of Interactive Marketing, Vol. 14, No. 1, pp. 15-29.

10 Bellman, S., Lohse, G. L. and Johnson, E. J. (1999) 'Predictors of online buying behavior', Communications of the ACM, Vol. 42, No. 12, December, pp. 32-38.

11 Li et al. (2001) op. cit.

12 Lohse, G. L. and Spiller, P. (1999) 'Internet retail store design: How the user interface influences traffic and sales', Journal of Computer-Mediated Communication, Vol. 5, No. 2. Available online at: http://www.ascusc.org/jcmc/vol5/issue2/lohse.htm.

13 Jarvenpaa and Tractinsky (1999) op. cit.

14 Jarvenpaa, S. L., Tractinsky, N., and Vitale, M. (2000) 'Consumer trust in an internet store', Information Technology and Management, Vol. 1, Nos. 1-2, pp. $45-71$.

15 Lowengart, O. and Tractinsky, N. (2001) 'Differential effect of product category on shoppers selection of web-based store: Probabilistic modelling approach', Journal of Electronic Commerce Research, Vol. 2, No. 4, pp. 12-26, available online at http://www.csulb.edu/web/journals/jecr/issues/ 20014/paper2.pdf.

16 Jarvenpaa et al. (2000) op. cit.

17 Gefen, D. (2000) 'E-commerce: The role of familiarity and trust', Omega: The International Journal of Management Science, Vol. 28, No. 5, pp. 725-737.

18 Lowengart and Tractinsky (2001) op. cit.

19 Jarvenpaa et al. (2000) op. cit.

20 Zhang and von Dran (2001) op. cit.

21 Zhang et al. (2001) op. cit.

22 Lowengart and Tractinsky (2001) op. cit.

23 Kotler, P. (2000) 'Marketing management', 10th edn, Prentice Hall, Englewood Cliffs, NJ.

24 Ibid.

25 Hooley, G. J. (1995) 'Positioning', in Baker, M. J. (ed.) 'Companion encyclopedia of marketing', Routledge, London, pp. 420-429.

26 Ibid.

27 Lowengart, O. and Menipaz, E. (2001) 'Positioning mapping as a tool for multinational corporations in selecting a country as a base of operation', Management Decision, Vol. 39, No. 4, pp. 302-314.

28 Kotler, P., Jatusripitak, S. and Maesincee, S. (1997) 'The marketing of nations', The Free Press, New York.

29 Wind, Y. and Mahajan, V. (2002) 'Convergence marketing', Journal of Interactive Marketing, Vol. 16, No. 2, pp. 64-79.

30 Iacobucci, D., Arabie, P. and Bodapati, A. (2000) 'Recommendation agents on the internet', Journal of Interactive Marketing, Vol. 14, No. 3, pp. 2-11.

31 Berthon et al. (2000) op. cit.

32 Lowengart and Tractinsky (2001) op. cit.

33 Ibid.

34 Grazioli, S. and Wang, A. (2001) 'Looking without seeing: Understanding unsophisticated consumers' success and failure to detect internet deception', Proceedings of the 22nd International 
Conference on Information Systems (ICIS) 2001, pp. 193-204.

35 Gefen, D., Rao, S. V. and Tractinsky, N. (2003)

'The conceptualization of trust, risk and their relationship in electronic commerce: The need for clarifications', Proceedings of the 36th Hawaii International Conference on System Sciences (CD/ROM), Island of Hawaii, 6th-9th January, 2003, Computer Society Press.

36 Lowengart and Tractinsky (2001) op. cit. 37 Ibid.

38 Wilkes, R. E. and Valencia, H. (1985) 'A note on generic purchaser generalizations and subcultural variations', Journal of Marketing, Vol. 49, pp. 114-120.

39 Bellizzi, J. A., Krueckeberg, H. R., Hamilton, J. R. and Martin, W. S. (1981) 'Consumer perception of national, private, and generic brands', Journal of Retailing, Vol. 57, pp. 56-70.

40 Lowengart and Tractinsky (2001) op. cit.

41 Urban, G. and Hauser, J. R. (1993) 'Design and marketing of new products', 2nd edn, Prentice-Hall, Englewood Cliffs, NJ.

42 Ibid. 